\title{
Cytotoxic Effects of Pistacia Atlantica (Baneh) Fruit Extract on Human KB Cancer Cell Line
}

\author{
Zohreh Jaafari-Ashkvandi ${ }^{1}$, Saeed Yousefi Shirazi ${ }^{2}$, Somayeh Rezaeifard ${ }^{3}$, Azadeh Hamedi ${ }^{4}$, \\ Nasrollah Erfani ${ }^{5, *}$
}

\begin{abstract}
Plants with anticancer properties are considered as cancer preventive and treatment sources, due to their some biological effects. Apoptosis induction and anti-proliferative effects of Baneh extract on various cancer cell lines have been reported. Hence, this study was designed to evaluate the cytotoxic effects of this fruit on KB and human gingival fibroblast cell lines (HGF). KB and HGF cells were treated with various concentrations of ethanolic Baneh extract and cisplatin as positive control. Cytotoxic activity and apoptosis induction were investigated using WST-1 and Annexin V assays. Data were analyzed using ANOVA and student's t-tests. IC F $_{50}$ after 24 and 48 hours treatment were respectively 2.6 and $1 \mathrm{mg} / \mathrm{mL}$ for KB cell line, and 1.5 and $1.6 \mathrm{mg} / \mathrm{mL}$ for HGF cell. During 48 hours Baneh extract induced apoptosis without significant necrosis, in a time- and dose-dependent manner. The induction of apoptosis in KB cells was significantly higher than HGF. It seems that ethanolic extract of Baneh contains compounds that can suppress KB cell growth through the induction of apoptosis. Within 48 hours, less cytotoxic effects were observed on normal fibroblast cells; therefore, it might be a potential anticancer agent.
\end{abstract}

\section{KEYWORDS}

pistacia; Baneh; squamous cell carcinoma; cytotoxicity; apoptosis; fibroblast; cell line

\section{AUTHOR AFFILIATIONS}

${ }^{1}$ Department of Oral \& Maxillofacial pathology, School of Dentistry, Shiraz University of Medical Sciences, Shiraz, Iran

${ }^{2}$ School of Dentistry, Shiraz University of Medical Sciences, Shiraz, Iran

${ }^{3}$ Shiraz Institute for Cancer Research, School of Medicine, Shiraz University of Medical Sciences, Shiraz, Iran

${ }^{4}$ Department of Pharmacognosy, School of Pharmacy, Shiraz University of Medical Sciences, Shiraz, Iran

${ }^{5}$ Department of Immunology and Shiraz Institute for Cancer Researches, School of Medicine, Shiraz University of Medical Sciences, Shiraz, Iran

* Corresponding author: Department of Immunology and Shiraz Institute for Cancer Researches, School of Medicine, Shiraz University of Medical Sciences, Shiraz, Iran; e-mail: erfanin@sums.ac.ir

Received: 25 September 2018

Accepted: 26 January 2019

Published online: 1 April 2019

Acta Medica (Hradec Králové) 2019; 62(1): 30-34

https://doi.org/10.14712/18059694.2019.43

(c) 2019 The Authors. This is an open-access article distributed under the terms of the Creative Commons Attribution License (http://creativecommons.org/licenses/by/4.0), which permits unrestricted use, distribution, and reproduction in any medium, provided the original author and source are credited. 


\section{INTRODUCTION}

Squamous cell carcinoma (SCC) is the most common head and neck cancer. Despite advances in the medical research and therapies, 5-years survival rate is not favorable, yet. Surgery is the first therapeutic management and many patients require adjuvant radio-and chemotherapy (1). These anticancer approaches induce many non-specific involuntary cellular effects, cell death, tissue toxicity and several complications in patients (2). Today, there is an ever growing interest toward herbal medicine to treat cancer, due to low tissue toxicity and specific toxic effects on cancer cells (3). Herbs can act as alternative and complementary medicine. Natural compounds can reduce inflammation and counteract chemotherapy resistant (4).

Pistacia atlantica (P. atlantica) is a member of Anacardiaceae family, which grows from the Mediterranean basin to central Asia. P. atlantica subsp. krudica, known as Baneh is distributed in west mountainous region of Iran. The unripe fruits and the seeds of the plant are widely used as edible fruit, as nuts or in foods. The oleo-gum resin of the plant as well as its fruits and seeds are used in Persian Traditional Medicine (PTM) for treating digestive, hepatic, skin and kidney diseases $(5,6)$. Recently, different parts of the plant has exhibited some biological effects, such as anti-arteriosclerosis, , anti-inflammatory, antifungal and antimicrobial effects as well as cytotoxic properties in various human cancer cell lines (7). The main goal of anticancer agents is to induce tumoral cell death and control cell cycle (8). Previous studies on the cytotoxic effects of P. atlantica have shown the induction of apoptosis in prostate, colon, lung and breast cancer cell lines (9-11). These effects mostly are contributed to neutralizing free radicals, metal chelating and regulating of enzymatic activity due to presence of some component, such as flavonoids and polyphenols in this plant (12).

Polyphenolic components of the plant could also regulate the cell cycle progression through regulating genes that are related to cell proliferation and apoptosis (13). P. atlantica extract down-regulated cyclin A protein and $S$-phase of cell cycle in human colon carcinoma cell line (10). Also, it has induced GO/G1 arrest and has decreased the expression of cyclin D1 and cyclin dependent kinase 4 (CDK4) in breast cancer cell line (11).

Due to the potential cytotoxic effects of Baneh extract on several human cancer cell lines, this study aimed to evaluate its cytotoxic effect on KB (subline of HeLa cells with oral cancer properties) and normal human fibroblast cell line of the oral cavity. KB cells initially isolated from an oral SCC, however, they have been reported to be contaminated with HeLa cells and are considered as a subline of the these cells (14).

\section{METHODS AND MATERIAL}

\section{PLANT MATERIALS}

Fresh fruit of Baneh (P. atlantica subsp. krudica) was collected in Fars province (April, 2016) and was authenticated by a pharmcognosist at Shiraz University of Medical Sciences. The fruits were grinded and then macerated in
$70 \%$ ethanol in a dark and closed glass container $(3 \times 48$ hours). The collected hydroalcoholic extract was concentrated by a rotary evaporator at $40^{\circ} \mathrm{C}$ and stored at $-20^{\circ} \mathrm{C}$.

\section{CELL LINE AND CULTURE}

$\mathrm{KB}$ cells and human gingival fibroblast cell line (HGF) were purchased from the Pasture Institute cell bank in Tehran, Iran. The cells were cultured in RPMI-1640 and DMEM (Biosera-UK) medium supplemented with $10 \%$ fetal calf serum, $1 \%$ penicillin and $1 \%$ streptomycin (Biosera-UK), respectively. The cell cultures were grown in a $5 \% \mathrm{CO}_{2}$ incubator at $37^{\circ} \mathrm{C}$.

\section{CYTOTOXICITY ASSAY}

Cell viability of both cell lines was assessed by WST-1 test. The cells were cultured in 96 well, flat-bottoms microplates with a final volume of $200 \mu \mathrm{L} /$ well. Total of 10,000 cell/ well were incubated in $5 \% \mathrm{CO}_{2}$ at $37^{\circ} \mathrm{C}$ for 24 hours. Then, Baneh extract with $0,0.25,0.5,0.75,1 \mathrm{mg} / \mathrm{mL}$ dilutions and also cisplatin with $0,20,40,80 \mu \mathrm{g} / \mathrm{mL}$ dilutions (as positive control) were added and incubated at $37^{\circ} \mathrm{C}, 5 \% \mathrm{CO}_{2}$. After 24 and 48 hours treatment, $10 \mu \mathrm{L}$ WST- 1 solution was applied to the wells and incubated for 4 hours, again. Finally, the wells were shaken for 1 minute and optical density (OD) was measured by spectrophotometry at $480 \mathrm{~nm}$ using multimode microplate reader. The culture medium background was subtracted from the results and cytotoxicity percentage was calculated by the following formula: (OD of treated cells/OD of control cells) $\times 100-100$.

Then, $\mathrm{IC}_{50}$ values - the concentration that inhabits $50 \%$ cell growt - were obtained by curve expert software, version 13, in plant extract and control groups. Each experiment was performed triplicate and the results were presented as mean \pm SD.

\section{ANNEXIN V/7AAD APOPTOSIS ASSAY}

$\mathrm{KB}$ and HGF cells were treated with $\mathrm{IC}_{50}, 1 / 2 \mathrm{IC}_{50}$ and $2 \times \mathrm{IC}_{50}$ concentrations of Baneh extract for 48 hours. The treated and untreated (control) cells were trypsinized and stained with Annexin V/7AAD (Ann V/7A) kit (BD, USA) to detect apoptotic and necrotic cells. The cells were detected by FACS Calibur flow cytometr (BD Biosciences, USA) and were analyzed using flow Jo software package. According to the manufacture's instruction, data were classified as: viable cells when the stained cells were: Ann (-), 7A (-), early apoptosis: Ann (+), 7A (-), Late apoptosis: Ann (+), 7A (+) and necrotic: Ann V (-), 7A (+). Each analysis was performed 3 times and the means were reported.

Data analyzed by SPSS, version 15 using ANOVA and Mann-Whitney tests.

\section{RESULTS}

\section{CELL VIABILITY ASSAY}

Cell viability was assessed by WST-1 at $24-48$ hours. IC $_{50}$ values for $\mathrm{KB}$ and HGF cells after treatment with Baneh extract and cisplatin are shown in Tablel. Baneh extract 
showed growth inhibition in a dose-and time-dependent manner in KB cells. In HGF cells, the more potent cytotoxic effect was found in 24 hours; however, after 48 hours $\mathrm{IC}_{50}$ was slightly elevated. Similar results were found in cells treated with cisplatin.

Tab. 1 Cytotoxic effect of Baneh extract and cisplatin after 24 and 48 hours on KB and HGF cells using WST-1 test.

\begin{tabular}{|l|c|c|c|c|}
\hline \multirow{2}{*}{ Agent } & \multicolumn{2}{|c|}{ IC $_{50}$ KB } & \multicolumn{2}{|c|}{ IC $_{50}$ HGF } \\
\cline { 2 - 5 } & $24 \mathrm{~h}$ & $48 \mathrm{~h}$ & $24 \mathrm{~h}$ & $48 \mathrm{~h}$ \\
\hline $\begin{array}{l}\text { Baneh extract } \\
(\mathrm{mg} / \mathrm{mL})\end{array}$ & $2.6 \pm 0.04$ & $1.0 \pm 0.02$ & $1.5 \pm 0.05$ & $1.6 \pm 0.03$ \\
\hline $\begin{array}{l}\text { Cisplatin } \\
(\mu \mathrm{g} / \mathrm{mL})\end{array}$ & $62 \pm 2.1$ & $14.6 \pm 1.8$ & $154.1 \pm 3$ & $193 \pm 3.5$ \\
\hline
\end{tabular}

\section{APOPTOSIS INDUCTION}

Apoptotic and necrotic KB and HGF cells were detected by Ann V/7A staining assay using flow cytometry after 48 hours. The profile of cell distribution is shown in Figures 1 and 2 . The percentage of viable, apoptotic and necrotic cells are found in Table 2 . Flow cytometric analysis of apoptosis in KB cell line after 48 hours incubation with different concentration of Baneh extract is illustrated in Figure 3 . According to the results, in KB cells a significant $(>60 \%)$ early apoptosis was induced after 48 hours with $1 \mathrm{mg} / \mathrm{mL}$ concentration. Also, there was no significant percentage of necrotic cells after 48 hours of treatment. HGF cells showed about $10 \%$ apoptosis during that time

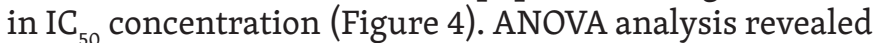
significant differences between the treated and untreated KB cells in the percentage of live, apoptotic and necrotic cells. Post-hoc Dunn analysis showed that the difference was significant between the percentages of the live and the early apoptotic populations, as well as between the early and the late apoptotic populations. Furthermore, ANOVA and Dunn analysis revealed this pattern to be repeated in treated and untreated HGF cells; however, there was no significant difference in the percentages of the late apoptotic and necrotic cells in this cell line (Table 2).

Tab. 2 The percentage of live, apoptotic and necrotic cells in all study cell lines.

\begin{tabular}{|c|c|c|c|}
\hline & Concentration & KB & HGF \\
\hline \multirow{2}{*}{ Live cell } & $\mathrm{IC}_{50}$ & $12.92 \pm 0.31^{*}$ & $88.73 \pm 1.00^{*}$ \\
\hline & Ctrl (0) & $91.45 \pm 0.20$ & $95.50 \pm 1.22$ \\
\hline \multirow{2}{*}{$\begin{array}{l}\text { Early } \\
\text { apoptosis }\end{array}$} & $I C_{50}$ & $74.00 \pm 0.10^{*}$ & $12.44 \pm 1.00^{*}$ \\
\hline & Ctrl & $6.13 \pm 0.05$ & $4.32 \pm 0.31$ \\
\hline \multirow{2}{*}{$\begin{array}{l}\text { Late } \\
\text { apoptpsis }\end{array}$} & $\mathrm{IC}_{50}$ & $12.62 \pm 0.34^{*}$ & $1.11 \pm 0.01$ \\
\hline & Ctrl & $2.33 \pm 0.18$ & $0.20 \pm 0.03$ \\
\hline \multirow{2}{*}{ Necrosis } & $\mathrm{IC}_{50}$ & $0.49 \pm 0.11$ & $0.18 \pm 0.05$ \\
\hline & Ctrl & $0.17 \pm 0.05$ & $0.05 \pm 0.00$ \\
\hline
\end{tabular}

* Significant when compare to control (using Dunn post-hoc test).

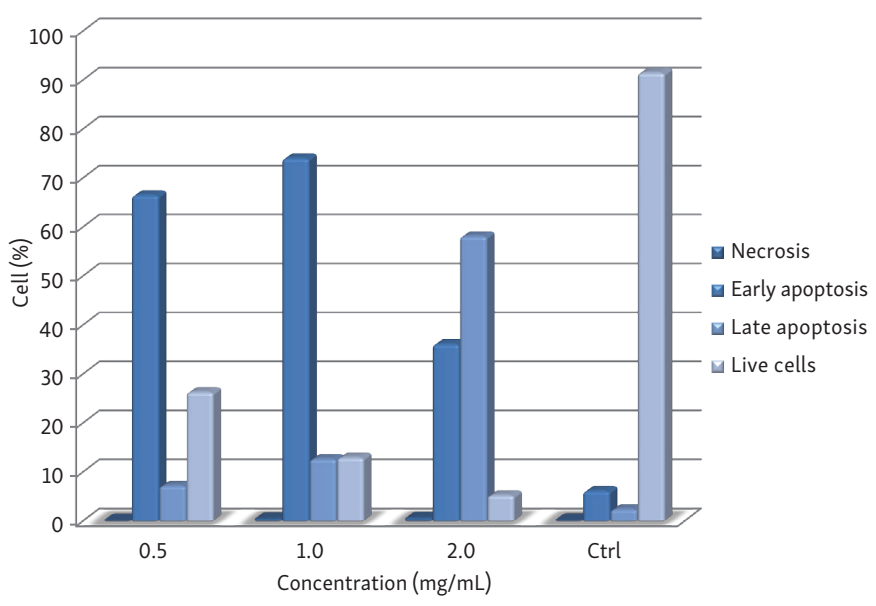

Fig. 1 Annexin V/PI apoptotic assay on Baneh extract treated KB cells after 48 hours.

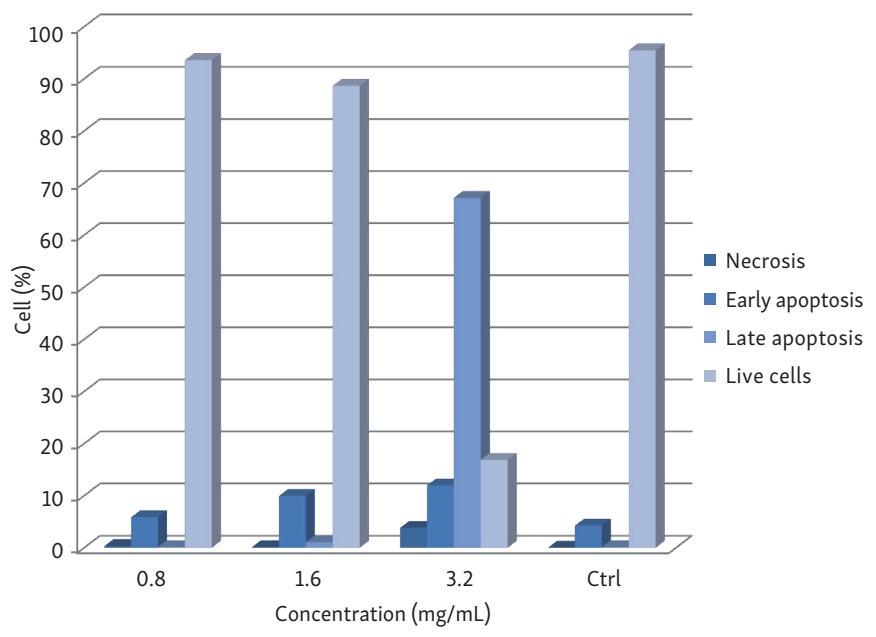

Fig. 2 Annexin V/PI apoptotic assay on Baneh extract treated HGF cells after 48 hours.

\section{DISCUSSION}

Insufficient apoptosis is a feature of cancer cells. The regulation of apoptosis is a promising target for many anti-cancer drugs (8). Recently, many herbal compounds are recognized with cytotoxic effects on various cancer cells, which can be used as lead compounds for developing new anticancer agents. Natural compounds exert chemotoxic effects via the induction of apoptotic pathways (15). In the present study, the cytotoxic effects of Baneh hydroalcoholic extract on KB and HGF cells were assessed by evaluating cell viability and apoptosis rate. The hydroalcoholic extract is enriched with bioactive polyphenolic compounds (16).

The results showed that Baneh extract exert cytotoxic effects on both cell lines, but it was more pronounced in $\mathrm{KB}$ cells after 48 hours. However, this cytotoxic effect was not very potent, especially on HGF cells. Extract IC ${ }_{50}$ values demonstrated that the plant could have cytotoxic compounds and these values could be a result of the additive effect of different compounds in extract. Flow cytometry assay after 48 hours defined that Baneh extract induced apoptosis without significant induction of necrosis. Apoptosis is a well-controlled cell death mechanism for removal 
A.

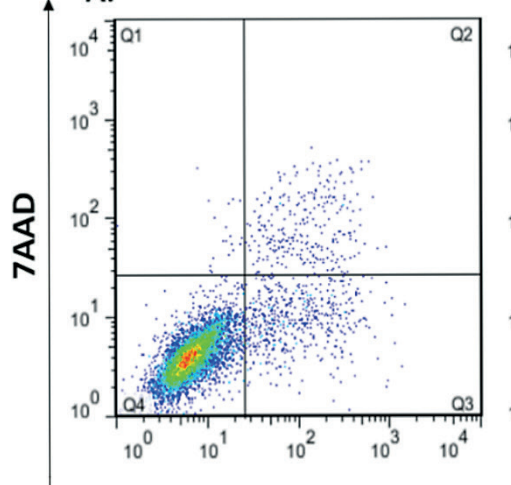

B.

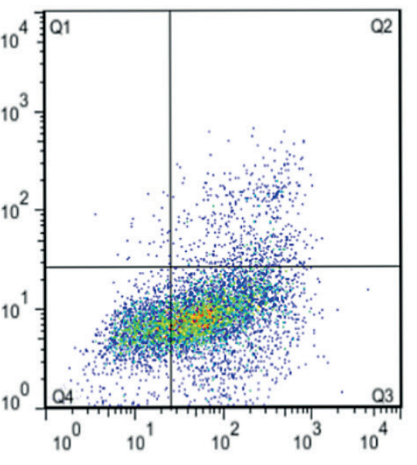

C.

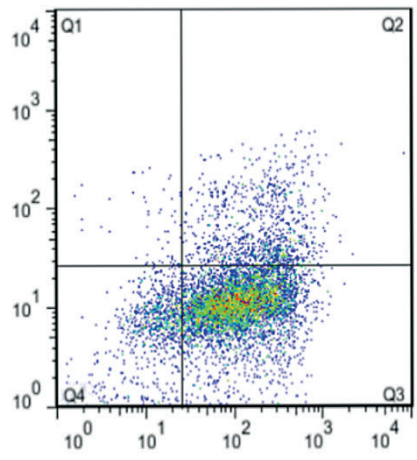

D.

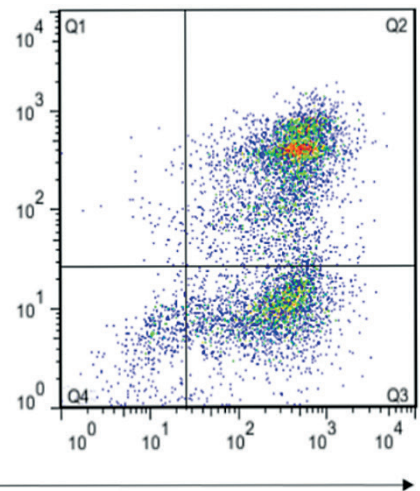

Annexin V

Fig. 3 Flow cytometric analysis of apoptosis in $\mathrm{KB}$ cell line after 48 hours treatment with different concentration of Baneh extract; A: untreated cells (control), B: 0.5, C: $1\left(\mathrm{IC}_{50}\right), \mathrm{D}: 2 \mathrm{mg} / \mathrm{mL}$ concentrations.

A.

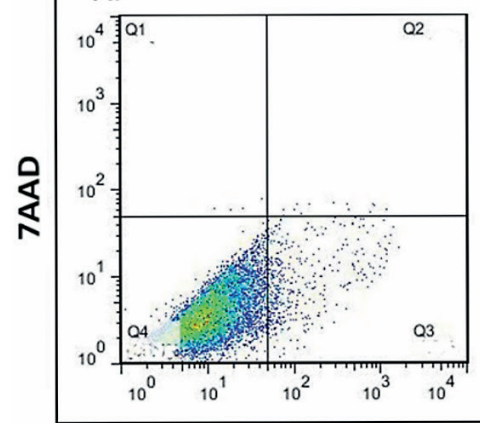

B.

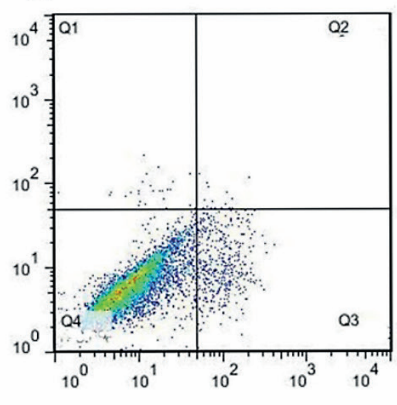

C.

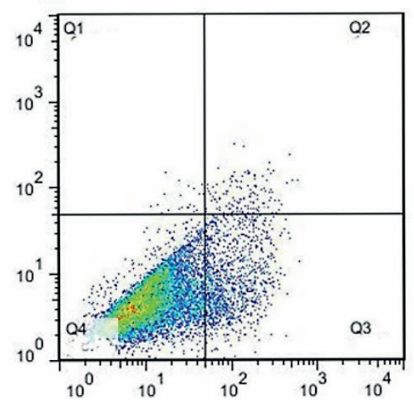

D.

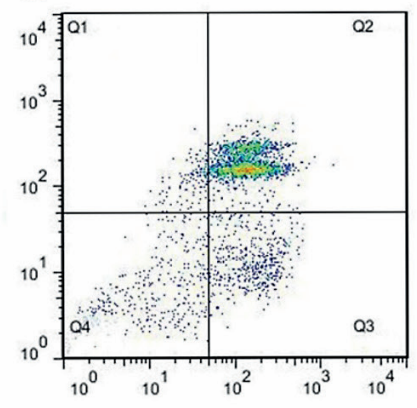

\section{Annexin V}

Fig. 4 Flow cytometric analysis of apoptosis in HGF cell line after 48 hours treatment with different concentration of Baneh extract; A: untreated cells (control), B: 0.8, C: $1.6\left(I_{50}\right), D: 3.2 \mathrm{mg} / \mathrm{mL}$ concentrations.

of damaged cells. There are two apoptotic pathways: extrinsic pathway, which is activated via membrane death receptors and intrinsic pathway, which is activated by alteration in mitochondrial membrane; both pathways result in activation of caspases. Insufficient apoptosis plays a crucial role in cancer development (13). Increased apoptosis and cell cycle arrest have been observed in some cancer cell lines in response to various extracts of Baneh. Rezaei et al. stated that treatment of TD47 cells (human breast cancer cell line) for 48 hours, entailed cell cycle arrest via downregulation of cyclin D1 and CDK4. Also, they found that apoptosis was increased to $30 \%$ in treated cells, which was more powerful than doxorubicin $(11,15)$.

In another study, they found that pericarp polyphenolic-rich extract of Baneh induced apoptosis and inhibited cell cycle progression (via delay in S-phase) in human colon carcinoma cells (HT29)(10). Amiri et al. observed apoptosis induction in prostate cancer cell line (PC3) after treatment with ethanolic Baneh skin extract (9).

Some studies reported that plants of Anacardiaceae family could induce apoptosis via different mechanisms. The leaves of Lithraea molleoides activated P53-independent apoptosis in hepatocellular carcinoma cell lines (17). Also, poly (ADP-ribose) polymerase (PARP) cleavage and caspase activation were induced by Semecarpus anacardium nut oil in leukemia and breast cancer cell lines $(12,18)$.
P. lentiscus extract lead to cleavage of procaspase- 3 and activation of caspase in oral cancer cells (19). Baneh extract caused a time-dependent activation of caspase 3 and PARP cleavage in TD47 cells (15).

Polyphenolic compounds including flavonoids and non-flavonoids were found in all parts of Baneh nut. Many polyphenols could act as potent anti-cancer agents due to their antioxidant properties $(9,20)$. Also, polyphenols have induced activation of apoptotic transcription factor and enhanced apoptosis in many cancer cells (12). Flavonoids arrested different cell cycle phases and reduced tumor growth in animal models (21).

According to the results of cell viability assay in 24 and 48 hours, Baneh extract induced more powerful cytotoxic effects on HGF cells in 24 hours; however, IC $_{50}$ was increased after 48 hours of treatment. This pattern was also found in the study of ethanolic extract of Baneh skin on mouse fibroblast cell line (L929) in comparison with PC3 cells. However, the researchers did not find a significant difference in cytotoxic effects of Baneh extract on L929 cell line after 48 and 72 hours (9). It seems that normal fibroblasts could become resistance to cytotoxic effects of the plant compounds over time. Furthermore, HGF cells are mesenchymal cells; hence, it is possible to react with herbal compounds in a different manner in comparison with neoplastic epithelial cells. 
There are two cell death mechanisms that can be induced by cytotoxic agents and drugs; apoptosis and necrosis. In the present study, Baneh extract increased apoptosis without significant necrosis. Necrosis can stimulate pro-inflammatory response that can lead to infiltration of immune cells in the tumor site. This process result in increasing effects of cytotoxic drugs, but also an inflammatory response can activate mitogens or cytokines and promote cell growth, migration and tumor metastasis (22, 23). Many anticancer agents, such as cisplatin, taxol and 5-fluorouracil (5-FU), which are routinely used for head and neck cancers, act via induction of both mechanisms (24). Furthermore; a few studies have shown that necrosis might be a preferred mechanism for anticancer treatments (25). Due to dual function of anticancer agents it is necessary to evaluate usefulness as well as side effects of any potential anticancer agent through in vivo studies. Further studies are expected to search for the exact mechanism of tumoral cell death, as well as monitoring the effect of Baneh extract on non-tumoral host tissues as well as emphasizing the clinically relevant action of this compound.

\section{CONCLUSION}

The study findings indicated that Baneh extract was able to induce apoptosis, without significant increase of necrosis in KB cells. During 48 hours, cytotoxic effect was more pronounced in KB cells rather than HGF. Based on the results, Baneh extract may contain metabolites, which could be considered as anticancer agents, however furthers studies are suggested to determine their structures and the possible mechanisms of action.

\section{ACKNOWLEDGEMENTS}

This manuscript is based on the undergraduate thesis of S. Yousefi Shirazi. The authors are grateful to Dr. M. Vosoughi at Dental Research Development Center of Shiraz Dental School. This research program was funded by Vice-chancellery of Shiraz University of Medical Sciences (Grant \#8895148). The authors wish to thank Mr. H. Argasi at the Research Consultation Center (RCC) of Shiraz University of Medical Sciences for his invaluable assistance in editing this manuscript.

\section{REFERENCES}

1. Mosel DD, Bauer RL, Lynch DP, Hwang ST. Oral complications in the treatment of cancer patients. Oral Dis 2011 Sep; 17(6): 550-9.

2. Astolfi L, Ghiselli S, Guaran V, et al. Correlation of adverse effects of cisplatin administration in patients affected by solid tumours: a retrospective evaluation. Oncol Rep 2013 Apr; 29(4): 1285-92.
3. Greenwell M, Rahman PK. Medicinal Plants: Their Use in Anticancer Treatment. Int J Pharm Sci Res 2015 Oct 1; 6(10): 4103-12.

4. Pistollato F, Calderón Iglesias $\mathrm{R}$, et al. The use of natural compounds for the targeting and chemoprevention of ovarian cancer. Cancer Letters 2017; 411: 191-200.

5. Bozorgi M, Memariani Z, Mobli M, Salehi Surmaghi MH, Shams-Ardekani MR, Rahimi R. Five Pistacia species (P. vera, P. atlantica, P. terebinthus, $P$. khinjuk, and $P$. lentiscus): a review of their traditional uses, phytochemistry, and pharmacology. The Scientific World Journal 2013; 2013: 219815.

6. Avicenna. The Canon. Tehran, Iran: Soroush Press; 2008.

7. Peksel A. Antioxidative properties of decoction of Pistacia atlantica Desf. leaves 2008.681-93 p.

8. Pfeffer CM, Singh ATK. Apoptosis: A Target for Anticancer Therapy. Int J Mol Sci 2018 Feb 2; 19(2): 448.

9. Amiri M, Kazerouni F, Namaki S, et al. Cytotoxic Effects of the Ethanol Bane Skin Extract in Human Prostate Cancer Pc3 Cells. Iran J Cancer Prev 2016 Apr; 9(2): e4755.

10. Rezaei PF, Fouladdel S, Hassani S, et al. Induction of apoptosis and cell cycle arrest by pericarp polyphenol-rich extract of Baneh in human colon carcinoma HT29 cells. Food and Chemical Toxicology 2012; 50(3): 1054-9.

11. Rezaei PF, Fouladdel S, Ghaffari SM, Amin G, Azizi E. Induction of $\mathrm{G} 1$ cell cycle arrest and cyclin D1 down-regulation in response to pericarp extract of Baneh in human breast cancer T47D cells. DARU Journal of Pharmaceutical Sciences 2012; 20(1): 1 .

12. Mathivadhani P, Shanthi P, Sachdanandam P. Apoptotic effect of Semecarpus anacardium nut extract on T47D breast cancer cell line. Cell Biology International 2007; 31(10): 1198-206.

13. Keating E, Martel F. Antimetabolic Effects of Polyphenols in Breast Cancer Cells: Focus on Glucose Uptake and Metabolism. Front Nutr 2018; 5: 25.

14. Jiang L, Zeng X, Wang Z, Chen Q. Cell line cross-con-tamination:KB is not an oral squamous cell carcinoma cell line. Eur J Oral Sci 2009; 117: $90-1$.

15. Rezaei PF, Fouladdel S, Cristofanon S, Ghaffari S, Amin G, Azizi E. Comparative cellular and molecular analysis of cytotoxicity and apoptosis induction by doxorubicin and Baneh in human breast cancer T47D cells. Cytotechnology 2011; 63(5): 503-12.

16. Suh SS, Kim SM, Kim JE, et al. Anticancer activities of ethanol extract from the Antarctic freshwater microalga, Botryidiopsidaceae sp. BMC Complementary and Alternative Medicine 2017 Dec 1; 17(1): 509.

17. Barbini L, Lopez P, Ruffa J, et al. Induction of apoptosis on human hepatocarcinoma cell lines by an alkyl resorcinol isolated from Lithraea molleoides. World Journal of Gastroenterology 2006 Oct 7; 12(37): 5959-63.

18. Chakraborty S, Roy M, Taraphdar AK, Bhattacharya RK. Cytotoxic effect of root extract of Tiliacora racemosa and oil of Semecarpus anacardium nut in human tumour cells. Phytotherapy research: PTR 2004 Aug; 18(8): 595-600.

19. Li S, Cha I-H, Nam W. Chios mastic gum extracts as a potent antitumor agent that inhibits growth and induces apoptosis of oral cancer cells. Asian Pac J Cancer Prev 2011; 12 (7): 1877-80.

20. Hatamnia AA, Abbaspour N, Darvishzadeh R. Antioxidant activity and phenolic profile of different parts of Bene (Pistacia atlantica subsp. kurdica) fruits. Food Chemistry 2014; 145: 306-11.

21. Sak K. Cytotoxicity of dietary flavonoids on different human cancer types. Pharmacognosy Reviews 2014 Jul; 8(16): 122-46.

22. Liu X, Yang W, Guan Z, et al. There are only four basic modes of cell death, although there are many ad-hoc variants adapted to different situations. Cell and Bioscience 2018; 8: 6 .

23. Ricci MS, Zong WX. Chemotherapeutic approaches for targeting cell death pathways. The Oncologist. 2006 Apr; 11(4): 342-57.

24. Elias ST, Borges GA, Rego DF, et al. Combined paclitaxel, cisplatin and fluorouracil therapy enhances ionizing radiation effects, inhibits migration and induces G0/G1 cell cycle arrest and apoptosis in oral carcinoma cell lines. Oncology Letters 2015 Sep; 10(3): 1721-7.

25. Zhang J, Lou X, Jin L, et al. Necrosis, and then stress induced necrosis-like cell death, but not apoptosis, should be the preferred cell death mode for chemotherapy: clearance of a few misconceptions. Oncoscience 2014; 1(6): 407-22. 